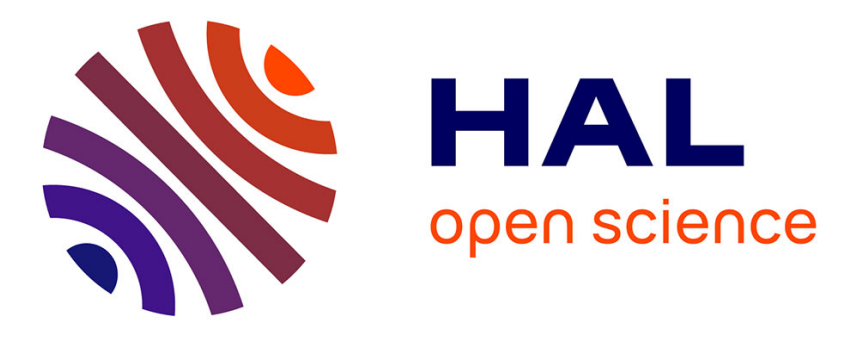

\title{
Prophenoloxidase system, lysozyme and protease inhibitor distribution in the common cuttlefish Sepia officinalis
}

Charles Le Pabic, Georges Safi, Antoine Serpentini, Jean-Marc Lebel, Jean-Paul Robin, Noussithé Kouéta

\section{To cite this version:}

Charles Le Pabic, Georges Safi, Antoine Serpentini, Jean-Marc Lebel, Jean-Paul Robin, et al.. Prophenoloxidase system, lysozyme and protease inhibitor distribution in the common cuttlefish Sepia officinalis. Comparative Biochemistry and Physiology - Part B: Biochemistry and Molecular Biology, 2014, 172-173, pp.96-104. 10.1016/j.cbpb.2014.04.009 . hal-00994223

\section{HAL Id: hal-00994223 \\ https://hal.science/hal-00994223}

Submitted on 21 May 2014

HAL is a multi-disciplinary open access archive for the deposit and dissemination of scientific research documents, whether they are published or not. The documents may come from teaching and research institutions in France or abroad, or from public or private research centers.
L'archive ouverte pluridisciplinaire HAL, est destinée au dépôt et à la diffusion de documents scientifiques de niveau recherche, publiés ou non, émanant des établissements d'enseignement et de recherche français ou étrangers, des laboratoires publics ou privés. 


\title{
Prophenoloxidase system, lysozyme and protease inhibitor distribution in the common cuttlefish Sepia officinalis
}

\author{
Le Pabic Charles ${ }^{\mathrm{a}, \mathrm{b}, \mathrm{c}} \#^{*}$, Safi Georges ${ }^{\mathrm{a}, \mathrm{b}, \mathrm{c}} \#$, Serpentini Antoine ${ }^{\mathrm{a}, \mathrm{b}, \mathrm{c}}$, Lebel Jean-Marc ${ }^{\mathrm{a}, \mathrm{b}, \mathrm{c}}$, Robin \\ Jean-Paul $^{\mathrm{a}, \mathrm{b}, \mathrm{c}}$, Koueta Noussithé $\mathrm{e}^{\mathrm{a}, \mathrm{b}, \mathrm{c}}$ \\ ${ }^{a}$ Normandie Université, F-14032 Caen, France \\ ${ }^{\mathrm{b}}$ UMR BOREA, MNHN, UPMC, UCBN, CNRS-7028, IRD-207, IBFA Université de Caen \\ Basse-Normandie, Esplanade de la Paix, CS 14032, 14032 Caen cedex, France \\ ${ }^{\mathrm{c}}$ Centre de Recherches en Environnement Côtier, Université de Caen Basse-Normandie, 54 \\ rue du Docteur Charcot, 14530 Luc-sur-Mer, France
}

\# These authors contributed equally to the study

*Corresponding author:

\author{
Charles Le Pabic \\ UMR BOREA, MNHN, UPMC, UCBN, CNRS-7028, IRD-207, \\ IBFA Université de Caen Basse-Normandie, Esplanade de la \\ Paix, CS 14032, 14032 Caen cedex, France \\ Tel.: (+33) 231565102 \\ Fax: (+33) 231565346 \\ e-mail : charles.lepabic@gmx.fr
}

\begin{abstract}
The immune system of cephalopods remains poorly understood. The aim of this study was to determine the specific activity of immune enzymes in epithelial barriers, circulatory and digestive systems of the common cuttlefish Sepia officinalis. Three enzyme groups with putative functions in immunity were investigated: phenoloxidases (POs), lysozymes and protease inhibitors (PIs). Consistent with role in immunity, highest PO activities were found in the integument as well as the respiratory and circulatory organs under zymogenic (proPO) and active form. Surprisingly, high PO activities were also found in the digestive gland and its appendages. Similarly, high lysozyme activities were detected in the integument and
\end{abstract}


31 circulatory organs, but also in the posterior salivary glands, highlighting the implication of this antibacterial enzyme group in most tissues exposed to the environment but also within the circulatory system. Albeit highest in digestive organs, the ubiquitous detection of PI activity in assayed compartments suggests immune function(s) in a wide range of tissues. Our study reports proPO/PO, lysozyme and PI distributions in S. officinalis body compartments for the first time, and thus provides the fundamental basis for a better understanding of the humoral immune system in cephalopods as well as invertebrates.

Keywords: cephalopod, immune system, lysozymes, prophenoloxidase system, protease inhibitors, Sepia officinalis

\section{Introduction}

Most aquatic organisms inhabit environments rich in bacteria and other microorganisms. Unlike air, water functions as a medium for both transport and growth of microbes (Gomez et al., 2013; Hansen and Olafsen, 1999; McFall-Ngai et al., 2010). Thus a critical function of the immune system of aquatic organisms is to provide a protection against this constant pathogenic threat (Iwanaga and Lee, 2005). What adaptations of the immune system allow aquatic species to thrive in these conditions? Unlike vertebrates, invertebrates rely on innate immunological mechanisms alone as defense against pathogens (Loker et al., 2004). Cellmediated defense mechanisms are mainly carried out by hemocytes, which behave like macrophages (Heath-Heckman and McFall-Ngai, 2011), while humoral factors take part in various functions such as pathogen recognition, signaling pathway activation, and invader ${ }^{1}$

${ }^{1}$ Footnote 1: Abbreviations: APO: activated phenoloxidase; BAPNA: Na-benzoyl-L-arginine 4-nitroanilide hydrochloride; $\mathrm{BH}$ : branchial hearts; BHA: branchial heart appendages; BSA: bovin serum albumin; $\mathrm{Cu}$ : copper; DG: digestive gland; DGA: digestive gland appendages; DMSO: dimethyl sulfoxide; HEW: hen egg white; Hcy: hemocyanin; L-DOPA: 3,4Dihydroxy-L-phenylalanine; PI: protease inhibitor; PO: phenoloxidase; proPO: 
51 elimination (Wang et al., 2013). Among them, we chose to focus on (1) one of the most effective signaling pathway of invertebrates - the melanization cascade, (2) one well-known hydrolytic enzyme group involved in pathogen elimination - the lysozymes, and (3) components of the immune proteolytic cascade, the protease inhibitors (PIs) (Amparyup et al., 2013; Cerenius et al., 2008; Fiołka et al., 2012; Herreweghe and Michiels, 2012; Rowley and Powell, 2007; Wang et al., 2013; Xue et al., 2009).

While a major immune mechanism among many invertebrate taxa, melanization remains understudied in mollusks. It is involved in (1) non-self recognition, (2) production of toxic compounds against pathogens, (3) wound healing and (4) cellular-defense factor synthesis (e.g. Cerenius et al., 2008; Luna-Acosta et al., 2010; Siddiqui et al., 2006). Phenoloxidases (POs), a family of copper $(\mathrm{Cu})$ proteins catalyse the rate-limiting step in melanin production: oxidation or hydroxylization of phenols into quinones. Importantly, POs are synthetized as zymogenic form called prophenoloxidases (proPO) and activated by serine protease cleavage (Amparyup et al., 2013; Cerenius and Söderhäll, 2004; Masuda et al., 2012). Because of their immune functions highest PO levels are usually found in association with epithelial barriers, respiratory and circulatory systems in arthropods and bivalves (Asano and Ashida, 2001; Franssens et al., 2008; Luna-Acosta et al., 2011a; Masuda et al., 2012; Zhou et al., 2012).

Lysozymes cleave the 1,4- $\beta$-glycosidic linkage between $\mathrm{N}$-acetylglucosamine and $\mathrm{N}$ acetylmuramic acid of bacteria cell walls in order to lyse the cell - a process used in both immune defense and gastric digestion (Herreweghe and Michiels, 2012). Apart from this antimicrobial property, lysozymes interact with immune system compounds (e.g. complement pathway, lectins, proPO) to modulate or enhance humoral immune response (Goto et al.,

prophenoloxidase; PSG: posterior salivary glands; SE: standard error; SH: systemic heart; Stc: stomach; TI: trypsin inhibition; WB: white bodies 
2007; Herreweghe and Michiels, 2012; Park et al., 2007; Rao et al., 2010; Wang and Zhang, 2010). Their chitinase activity is also used to ward off fungal infection (Herreweghe and Michiels, 2012). Consistent with these properties they are mainly associated with the epithelial barriers, respiratory and circulatory systems of numerous aquatic organisms such as bivalves and fish, and in some cases digestive tracts of bivalves because of their use of bacteria as food (Herreweghe and Michiels, 2012; Saurabh and Sahoo, 2008).

Finally, PIs aid in the defense of various organisms by regulating or inhibiting bacterial protease activities through interaction with their reaction sites or entrapment. PIs also play a central role in the regulation of a wide variety of immune processes including (1) hemolymph coagulation, (2) proPO activation and (3) synthesis of cytokines and antimicrobial peptides (Xue et al., 2009). However, PIs also take part in other processes such as digestion, where protease regulation is necessary and are consequently not concentrated in tissues with immune functions.

Cephalopods are a highly derived group in the molluscan clade, with a complex nervous system allowing elaborate body patterning and behaviour, a deeply modified body plan organization, and highly diverse modes of life (Bassaglia et al., 2013; Hanlon and Messenger, 1988). However little is known about their immune system (Castellanos-Martínez and Gestal, 2013; Ford, 1992). Furthermore, cephalopods possess anatomical peculiarities within mollusks such as a closed circulatory system with a central systemic heart $(\mathrm{SH})$ and two branchial heart (BH) complexes (Schipp, 1987), as well as clearly identified hematopoietic organs - the white bodies (WB) (Claes, 1996), suggesting immune pathway modifications. Yet, immune involvement of POs has never been studied in cephalopods, only one study reported lysozyme repartition in the octopod Eledone cirrhosa (Malham et al. 1998), and PI activity was mostly described in the plasma (Armstrong, 1992; Thøgersen et al., 1992; 
Vanhoorelbeke et al., 1994), and the digestive gland of several species (Ishikawa et al., 1966; Kishimura et al., 2010, 2001; Sof'ina et al., 1988).

Based on previously described enzyme repartitions and roles, we hypothesized that (1) higher proPO/PO- and lysozyme-activities would be found in the circulatory system and tissues directly exposed to the outer environment in Sepia officinalis: plasma, BH and their appendages (BHA), SH, WB, integument, mantle and gill, and (2) that PIs would be ubiquitous in S. officinalis compartments because of the general need to regulate proteases.

Here, we report the distribution of proPO/PO, lysozymes and PIs in 13 body compartments selected for their functions in circulation, respiration, immunity, digestion or as physical barriers in adult common cuttlefish: respiratory and circulatory compartments (gill, plasma, $\mathrm{SH}, \mathrm{BH}, \mathrm{BHA}$, and $\mathrm{WB}$ ), digestive organs (posterior salivary glands (PSG), stomach (Stc), cecum, digestive gland (DG) and its appendages (DGA)), and integument and mantle, as first epithelial barrier and underlying muscle tissue, respectively. Higher activated PO (APO)- and lysozyme-activities were mainly found in the integument, circulatory and respiratory organs consistent with a role in immunity. In addition, we found high POactivities in the DG, potentially highlighting its role(s) in protection of the digestive tract against infections and/or hemocyanin (Hcy) metabolism. Lastly, higher PI-activities were mostly found in digestive system organs despite their presupposed ubiquitous repartition.

\section{Material and methods}

\subsection{Animals and tissue samples}

Ten adult common cuttlefish $S$. officinalis (mean \pm standard deviation; weight $=1.03 \pm$ $0.38 \mathrm{~kg}$; dorsal mantle length $=21.3 \pm 3.5 \mathrm{~cm}$ ) were obtained from traps deployed along the Calvados coast (Basse-Normandie, France) during summer 2012. Prior to experimentation, 
the animals were maintained in 4500-liter tanks in an open seawater circuit and starved for 24

$121 \mathrm{~h}$ at $15^{\circ} \mathrm{C}$ at the Centre de Recherches en Environnement Côtier (C.R.E.C., Luc-sur-Mer, Basse-Normandie, France).

In order to study basal enzymatic activities in cuttlefish tissue, we used animals without

124 visible wounds, with normal swimming behavior and predatory behavior display upon prey 125 presentation. We also carefully visually checked for the absence of macroscopic parasites in 126 animals and organs sampled. Following ethical procedures (Directive 2010/63/EU), cuttlefish were anesthetized as described by Andrews et al. (2013) through placement for $10 \mathrm{~min}$ in seawater containing $2 \%$ ethanol. Five $\mathrm{ml}$ hemolymph was then withdrawn from anterior mantle vein (King et al., 2005) using syringe with 18-gauge needle and kept in ice, and

130 animals killed by rapid decapitation. Digestive gland, DGA, PSG, Stc, cecum, WB, SH, gill,

131 BHs and BHA were then harvested and placed on ice. In addition, pieces of mantle and integument (with associated mucus) were sampled (Fig. S1). At the end of the dissection, tissues were rinsed in cold extraction buffers and kept at $-80^{\circ} \mathrm{C}$ until enzyme extraction.

134 Hemolymph samples were centrifugated at $500 \mathrm{~g}$ to separate plasma and hemocyte fractions, 135 and cell-free plasma was stored at $-80^{\circ} \mathrm{C}$ until analysis.

\subsection{Chemicals}

Aprotinin, Na-benzoyl-L-arginine 4-nitroanilide hydrochloride (BAPNA), bovin serum albumin (BSA), Bradford reagent, calcium chloride $\left(\mathrm{CaCl}_{2}\right)$, citric acid $\left(\mathrm{C}_{6} \mathrm{H}_{8} \mathrm{O}_{7}\right)$,

139 dimethyl sulfoxide (DMSO), hen egg white (HEW) lysozyme, 3,4-dihydroxy-L140 phenylalanine (L-DOPA), magnesium chloride $\left(\mathrm{MgCl}_{2}\right)$, freeze-dried Micrococcus 141 lysodeikticus, Protease Inhibitor Cocktail, sodium chloride ( $\mathrm{NaCl})$, sodium phosphate dibasic 142 dihydrate $\left(\mathrm{Na}_{2} \mathrm{HPO}_{4} \cdot 2 \mathrm{H}_{2} \mathrm{O}\right)$, trizma base, trizma hydrochloride (Tris- $\mathrm{HCl}$ ), tropolone and 143 trypsin TPCK (N-tosyl-L-phenylalanyl chloromethyl ketone) were obtained from Sigma- 
144 Aldrich (France). Halt Protease Inhibitor Cocktail, EDTA-Free (100X) was obtained from

145 Thermo Fisher Scientific (Waltham, USA).

\subsection{Enzyme extraction}

Tissue samples were weighed before to be ground in liquid nitrogen. Once a fine powder was obtained, the sample was homogenised in a known amount (10 $\mathrm{ml}$ to $1 \mathrm{~g})$ of cold Tris buffer $\mathrm{pH} 8(10 \mathrm{mM}$ Tris- $\mathrm{HCl}$ and $150 \mathrm{mM} \mathrm{NaCl})$ for lysozyme and PI assays (Safi, 2013) or Tris buffer $\mathrm{pH} 7\left(0.1 \mathrm{M}\right.$ Tris- $\mathrm{HCl}, 0.45 \mathrm{M} \mathrm{NaCl}, 26 \mathrm{mM} \mathrm{MgCl} 2$ and $\left.10 \mathrm{mM} \mathrm{CaCl}_{2}\right)$

151 for PO assay (Luna-Acosta, 2010). The mixture was homogenized, stored at $4^{\circ} \mathrm{C}$ for $1 \mathrm{~h}$, and

152 then centrifuged for $10 \mathrm{~min}$ at $15,000 \mathrm{~g}$ and $4{ }^{\circ} \mathrm{C}$. The resulting supernatant containing Tris

153 soluble proteins was collected for enzymatic studies.

\subsection{Biochemical analysis}

\subsubsection{Protein assays}

All activities were expressed in relation to protein concentration measured according to

157 the Bradford method (1976) using BSA as standard.

\subsubsection{PO assays}

In order to partly discriminate PO synthesis and activation site, we took care to avoid

160 unwanted activation of proPO during each step of experiment. PO-like activity was measured

161 spectrophotometrically by recording the formation of $o$-quinones, as described by LunaAcosta (2010) with slight modifications to distinguish artificially activated PO (APO)

163 (corresponding to PO-like activity resulting from zymogenic PO (proPO) activation plus

164 already 'active' form) and in vivo 'active' PO form. PO assays were conducted in triplicate in

165 96-well flat bottom plates (BD, USA). L-DOPA was used as substrate, at a final concentration 
166 of $10 \mathrm{mM}$ (Luna-Acosta, 2010), and prepared extemporaneously in Tris buffer $\mathrm{pH} 7$ described 167 above (section 2.3.). Tropolone $(10 \mathrm{mM})$ and trypsin TPCK $\left(1 \mathrm{~g} \mathrm{l}^{-1}\right)$ were used respectively as 168 PO inhibitor and elicitor as described by Lacoue-Labarthe et al. (2009) on S. officinalis 169 embryo. To avoid uncontrolled proPO activation by tissue endogenous proteases, several 170 wide spectrum PIs were tested: aprotinin $\left(1 \mathrm{~g} \mathrm{l}^{-1}\right)$, Protease Inhibitor Cocktail $(\mathrm{D} / 100)$ and 171 Halt Protease Inhibitor Cocktail, EDTA-Free (1X). For each sample, non-enzymatic sample autoxidation, 'basal', 'inhibited' and 'activated' PO-like activities were measured. For nonenzymatic sample autoxidation, $10 \mu \mathrm{l}$ of sample was mixed with Tris buffer $\mathrm{pH} 7$. For 'basal' PO-like activity, $10 \mu \mathrm{l}$ of sample was firstly mixed during 10 min with $1.4 \mu 1$ PI (100X), 175 followed by adapted volume of Tris buffer $\mathrm{pH} 7$ and $80 \mu 1$ L-DOPA. Similarly, for inhibited 176 or APO-like activity, $10 \mu \mathrm{l}$ of sample was mixed with $10 \mu \mathrm{l}$ of tropolone $(140 \mathrm{mM})$ or trypsin 177 TPCK $\left(14 \mathrm{~g} \mathrm{l}^{-1}\right)$, Tris buffer $\mathrm{pH} 7$ and $80 \mu \mathrm{L}$ L-DOPA. Each measurement was systematically controlled by replacing sample by buffer, always in a final reaction volume of $140 \mu 1$. Immediately after L-DOPA addition, PO-like activities were monitored at $25^{\circ} \mathrm{C}$ for $5 \mathrm{~h}$ using 180 Mithras LB 940 luminometer (Berthold, Thoiry, France) at $490 \mathrm{~nm}$ (Luna-Acosta, 2010).

181 When an inhibited PO-like activity was measured, this value was subtracted from APO and 182 PO-like activities. Tropolone, with its copper chelator and peroxidase substrate properties, 183 ensured that PO-like activity alone was detected (and not peroxidase). Results were also 184 systematically corrected for non-enzymatic autoxidation of the substrate and were expressed 185 in enzyme unit $(1 \mathrm{U})$ per $\mathrm{mg}$ of total protein. One $\mathrm{U}$ corresponded to an increase of $0.001 \mathrm{in}$ 186 the absorbance per min at $25^{\circ} \mathrm{C}$ (Thomas-Guyon et al., 2009). Preliminary assays showed similar effects on PO-like activity with aprotinin $\left(1 \mathrm{~g} \mathrm{l}^{-1}\right)$, 188 Protease Inhibitor Cocktail (D/100) and Halt Protease Inhibitor Cocktail - EDTA-Free (1X), 189 with concentrations inhibiting $1 \mathrm{~g} \mathrm{l}^{-1}$ elicitor trypsin TPCK, which is much higher than 190 maximal tissue intrinsic serine protease concentrations found in these compartments (not 
191 shown). Consequently, Halt Protease Inhibitor Cocktail - EDTA-Free was used in our study.

192 The use of a PI Cocktail to avoid unwanted in vitro proPO activation by tissue endogenous

193 proteases allowed to distinguish PO-like activities from already activated form when

194 sampling occurred, and those from inactive zymogenic form proPO at the same moment.

195 Therefore, in addition to activity levels, PO and APO-like activities informed us about proPO

196 location and compartments where proPO activation occurs most often, i.e. compartments most

197 submitted to uncontrolled elicitors (intern or extern).

\subsubsection{Lysozyme assay}

Lysozyme-like activity was quantified according to Malham et al. (1998) with slight

2.3.) standard was serially diluted and placed in triplicate in 96-well flat bottom plates (BD,

202 USA), as well as $50 \mu \mathrm{l}$ of each sample and $50 \mu \mathrm{l}$ of Tris buffer $\mathrm{pH} 8$, as blank. One hundred 203 and fifty $\mu \mathrm{l}$ of the substrate, M. lysodeikticus $[0.075 \mathrm{~g} / 100 \mathrm{ml}$ of phosphate/citrate buffer $\mathrm{pH}$ $5.8\left(\mathrm{Na}_{2} \mathrm{HPO}_{4} \cdot 2 \mathrm{H}_{2} \mathrm{O}, 4.45 \mathrm{~g} / 250 \mathrm{ml}\right.$ distilled $\mathrm{H}_{2} \mathrm{O} ; \mathrm{C}_{6} \mathrm{H}_{8} \mathrm{O}_{7}, 2.1 \mathrm{~g} / 100 \mathrm{ml}$ distilled $\mathrm{H}_{2} \mathrm{O} ; \mathrm{NaCl}$, $0.09 \mathrm{~g} / 100 \mathrm{ml}$ buffer)], was then added to each well. The reductions in turbidity in the wells were read on Mithras LB 940 luminometer (Berthold, Thoiry, France) at $25^{\circ} \mathrm{C}$ for 5 minutes at 10 second intervals at $450 \mathrm{~nm}$ using negative kinetics. Lysozyme concentrations were

208 calculated from the standard curve ( $\mu \mathrm{g}$ HEW lysozyme equivalent $\mathrm{ml}^{-1}$ ). Final lysozyme-like 209 activity was thus expressed as $\mu$ g HEW lysozyme eq. mg protein ${ }^{-1}$.

\subsubsection{PI assay}

As described by Malham et al. (1998) and Thompson et al. (1995), PI activity was

212 measured by transferring $20 \mu \mathrm{l}$ of sample and $10 \mu \mathrm{l}$ of trypsin TPCK (100 $\mu \mathrm{g} \mathrm{ml}^{-1}$ of $0.05 \mathrm{M}$

213 Tris buffer $\mathrm{pH}$ 8) in 96-well flat bottom plates (BD, USA), and mixed at room temperature for

2145 minutes. In parallel, intrinsic trypsin activity was measured by replacing $10 \mu 1$ of trypsin by 
215 Tris buffer $\mathrm{pH} 8$ described in section 2.3. A positive control was used by replacing the sample

216 with Tris buffer $\mathrm{pH}$ 8. Two hundred $\mu$ of BAPNA substrate solution $\left(5.2 \mathrm{mg}\right.$ BAPNA ml ${ }^{-1}$

217 DMSO in $10 \mathrm{ml}$ of $0.01 \mathrm{M}$ trizma base buffer $\mathrm{pH}$ 7.4) was added to each well and incubated

218 for 15 minutes at room temperature. Absorbance was read at $405 \mathrm{~nm}$ using Mithras LB 940

219 luminometer (Berthold, Thoiry, France), and PI activity was expressed as the percentage of

220 sample trypsin inhibition (TI) compared to the positive control. As most proteinaceous 221 protease inhibitors specifically inhibit proteolytic enzymes of one of four mechanistic classes

222 (i.e., aspartic proteases, cysteine proteases, metalloproteases and serine proteases) by 223 interacting with their reactive sites, this assay allowed quantifying serine PIs (Xue et al., 224 2009). PI activity $=[$ O.D.405nm $($ sample + trypsin + S $)-$ O.D.405nm $($ sample + S) $] /$ O.D.405nm $225(\operatorname{trypsin}+\mathrm{S}) \times 100$. Final activity was expressed as TI $\% \mu \mathrm{g}$ of $\operatorname{protein}^{-1}$.

\subsection{Statistical analysis}

All results are given as mean \pm standard error (SE) for adult organs. Residual distribution was tested for normality (Shapiro test) and homogeneity of variances (Levene test). In some cases, logarithmic $\left(\log _{10}\right)$ or reciprocal transformations were used to meet the

230 underlying assumptions of normality and homogeneity of variances. For normal values, one231 way analysis of variance (ANOVA) were used followed by non parametric pairwise 232 permutational $t$-tests $(\mathrm{n}<30)$. Significant differences between PO-like and APO-like 233 activities were tested for each organ with a Student's $t$-test. Statistical significance threshold 234 was set at $\mathrm{p}<0.05$. R software was used for statistics and graphics. 
Based on previously described enzyme repartitions and roles, we hypothesized that higher proPO/PO-activity would be found in the circulatory system and tissues directly exposed to the outer environment in S. officinalis.

The highest APO-like activity was measured in the integument $\left(12.2 \pm 1.5 \mathrm{U} \mathrm{mg} \mathrm{prot}^{-1}\right)$, consistent with its role as first epithelial barrier (Figure 1). A role of POs in cuttlefish wound healing was suggested by tissue thickening and darkening (Harms et al., 2006) similar to the proPO induced sclerotization and pigmentation process of the insect cuticle (Arakane et al., 2005; Pryor, 1940). Apart from their roles in immunity, POs may be involved in cuttlefish body patterning by chromatophore melanogenesis although melanin presence as pigment in the cephalopod integument remains controversial (see Messenger, 2001). Future studies will

247 have to determine PO implication in one or both processes in S. officinalis integument as 248 already shown in vertebrates (Haffner and Wieser, 1981; Mackintosh, 2001; Zanna et al., 249 2009). It is also noteworthy that the mantle, the main body part in direct contact with the 250 integument did not present any PO activity, suggesting local proPO synthesis. Similar PO 251 repartition was recently reported in bivalve mollusks with high and low activities in mantle 252 and muscle, respectively (Luna-Acosta et al., 2011b; Zhou et al., 2012).

In the plasma, POs and Hcy share a structurally and functionally equivalent active site 254 (Campello et al., 2008), yet POs are synthetized as inactive zymogenic form while Hcy is not. 255 In addition, Hcy constitutes more than $90 \%$ of the total plasma protein content (D'Aniello et 256 al., 1986; Ghiretti, 1966; Mangold and Bidder, 1989). Consequently, parallel assays of APO257 and PO-activities allowed to distinguish between Hcy- and non-Hcy-associated PO activities, 258 as PO-activity mostly resulted from Hcy oxidation (Siddiqui et al., 2006). The plasma was 259 indeed the only compartment where PO- and APO-like activities were similar $(2.6 \pm 0.3 \mathrm{U} \mathrm{mg}$ 
$\operatorname{prot}^{-1}$ ), strongly suggesting that (1) plasma PO-activity was mostly Hcy-associated and that (2) PO-activity from other compartments is mostly associated with PO enzymes. It is thus interesting to note that, except for the mantle, all studied compartments presented some APOlike activity, consistent with a wide role of POs in cuttlefish immunity (Figure 1). The previously suggested lectin role of Hcy and the Hcy-derived PO activity found in our study, as well as in other cephalopods, are consistent with recently reviewed roles of Hcy as an integral component of invertebrate innate immunity and suggest a function in immune response trigger (Alpuche et al., 2010; Amparyup et al., 2013; Campello et al., 2008; Coates and Nairn, 2014; Rögener et al., 1985; Siddiqui et al., 2006; Wang and Wang, 2013). around $7 \mathrm{U} \mathrm{mg}$ prot $^{-1}$ (except WB) with only PO-like activity found in $\mathrm{BH}(1.0 \pm 0.3 \mathrm{U} \mathrm{mg}$ $\left.\operatorname{prot}^{-1}\right)$. Such results are consistent with PO role(s) associated with the immune system: nonself recognition, antibacterial compound synthesis and production of factors stimulating cellular defense (Cerenius et al., 2008; Söderhäll and Cerenius, 1998). The low PO-like activity measured in $\mathrm{BH}$ could not be ascribed to either Hcy or POs, because of the role of $\mathrm{BH}$

275 cells (i.e. rhogocytes and adhesive hemocytes) in hemolymph epuration of xenobiotics and 276 allogenic substances (Beuerlein and Schipp, 1998; Beuerlein et al., 2002), and their 277 involvement in Hcy catabolism suggested by Beuerlein et al. (1998). Finally, high APO278 activity with lack of 'basal' PO-like activity in BHA was consistent with the Hcy extracellular 279 storage suggested by Beuerlein et al. (2000). WB APO-like activity $\left(2.4 \pm 1.0 \mathrm{U} \mathrm{mg} \operatorname{prot}^{-1}\right)$ 280 suggested proPO presence in hemocytes before their release in cuttlefish plasma.

As expected, APO- and PO-like activities measured in the digestive system were lower 282 than in other systems, except for the DG-DGA complex $\left(9.8 \pm 1.0\right.$ and $5.5 \pm 1.2 \mathrm{U} \mathrm{mg} \mathrm{prot}^{-1}$, 283 respectively), which presented higher APO-like activities than Stc, cecum and PSG (2.0 \pm 0.7 , 
$2841.8 \pm 0.6$ and $1.5 \pm 0.5 \mathrm{U} \mathrm{mg} \operatorname{prot}^{-1}$, respectively). DGA are known to carry out 2 main roles in S. officinalis; absorption of small molecules from digestion (Boucaud-Camou and BoucherRodoni, 1983; Boucaud-Camou and Pequignat, 1973), and osmoregulation via salts and water absorption to maintaining the internal hyperosmotic status of cephalopods (Schipp and Boletzky, 1976; Wells and Wells, 1989). Since no known link exists between PO function and digestion, DGA-associated proPO may reflect a role in the immune response, perhaps by providing protection against pathogen exposure from oral or rectal uptake of seawater, which occurs without exposure to digestive enzymes. In the case of the DG, PO-like activities were previously detected in mollusk DGs but no tissue-specific function was proposed (Blaschko and Hawkins, 1952; Blaschko, 1941; Luna-Acosta et al., 2011a, 2011b). In cephalopods, most of reported parasite infections (i.e. coccidians of the genus Aggregata, cestodes, trematodes, nematodes) were found in the digestive tract (reviewed in Castellanos-Martínez and Gestal, 2013; Hochberg, 1990). Because of (1) the high efficiency of melanization against parasites (Rao et al., 2010), (2) the important secretory ability of the DG and (3) its central position in 298 the digestive tract, we propose that the DG may serve as proPO reservoir to fight this type of 299 infection. In addition, the ability of some POs (i.e. laccases) to catalyze aromatic oxidation 300 (Dodor et al., 2004; Luna-Acosta et al., 2011a) and the high PO-like activities found in the 301 DG may also be linked to the detoxification of these compounds known to be highly 302 accumulated in cephalopods (e.g. Ansari et al., 2012; Won et al., 2009; Yamada et al., 1997). 303 In contrast, high PO-like activity $\left(5.7 \pm 1.7 \mathrm{U} \mathrm{mg} \mathrm{prot}^{-1}\right)$ reflects a potential role in $\mathrm{Hcy} \mathrm{Cu}-$ 304 metabolism. Because of its high Cu content (Bustamante et al., 2006; Miramand and Bentley, 305 1992; Miramand and Guary, 1980; Schipp and Hevert, 1978), many studies suggested a DG 306 implication in Hcy metabolism in S. officinalis (Costa et al., 2014; Decleir et al., 1978; 307 Lemaire et al., 1977; Martoja and Marcaillou, 1993; Schipp and Hevert, 1978), as 308 demonstrated in DG relatives (i.e. hepatopancreas and midgut gland) of arthropods, 
gastropods, and cephalopods (Burmester, 2002; Manubens et al., 2010; Ruth et al., 1996). In

310 S. officinalis, Cu-free Hcy synthesis takes place mainly in branchial glands (Schipp and

311 Hevert, 1978; Schipp et al., 1973), but the organ where Cu-binding takes place has not been 312 clearly determined (Decleir et al., 1976; Schipp and Hevert, 1978). Based on (1) low free 313 form $\mathrm{Cu}$ concentration found in the hemolymph (D'Aniello et al., 1986), (2) the association of 314 Cu with Hcy-size proteins in the DG (Bustamante et al., 2006; Rocca, 1969), and (3) the Hcy 315 exchanges taking place across the DG basal membrane (Martoja and Marcaillou, 1993), our data (PO-like activity) add up to this mounting evidence that the DG may function as $\mathrm{Cu}-$ 317 binding site for Hcy. found in circulatory system organs and integument as tissue directly exposed to environment. High activities found in DG complex organs will need further investigations to better define PO role(s) at this location, with potential links with detoxification and Hcy metabolism.

\subsection{Lysozyme distribution}

As with $\mathrm{PO} /$ proPO, we hypothesized that higher lysozyme-activities would be found in the circulatory system and tissues directly exposed to the outer environment in S. officinalis: plasma, $\mathrm{BH}$ and their appendages (BHA), $\mathrm{SH}, \mathrm{WB}$, integument, mantle and gill. All compartment samples indicated some lysozyme-like activities, except for the DGA (Figure 2).

Our results support our hypothesis and highlight the importance of lysozymes in circulatory system organs and epithelial barriers, but also in one organ involved in digestive processes, the PSG. As with APO activity, one of the highest levels was found in the integument with

330 lower activity in the mantle $\left(2.2 \pm 0.9\right.$ and $0.9 \pm 0.3 \mu \mathrm{g}$ HEW lysozyme eq. mg protein ${ }^{-1}$, 331 respectively). This high level is likely linked to the constant integument exposure to high 332 numbers of opportunistic pathogens in water as described in fish skin (Ghafoori et al., 2014; 
333 Hikima et al., 2001; Saurabh and Sahoo, 2008). Similarly, important lysozyme activity or 334 mRNA expression have been detected in mantle of gastropod Haliotis discus discus (Bathige 335 et al., 2013) and bivalve mollusks Venerupis philippinarum (Zhao et al., 2010), Crassostrea 336 virginica (Itoh et al., 2007) and C. gigas (Itoh et al., 2010). This localization is thus consistent 337 with previous descriptions in fish and bivalve mollusks and may reflect lysozyme activity in 338 neutralizing pathogens after injuries or bacterial infection. $\left(1.7 \pm 0.5,1.4 \pm 0.4,1.3 \pm 0.5\right.$ and $0.8 \pm 0.2 \mu \mathrm{g}$ HEW lysozyme eq. mg protein ${ }^{-1}$, 341 respectively), but not in the plasma $(<0.1)$. These results parallel lysozyme-like activities 342 found in the BH complex of the cephalopod E. cirrhosa (Malham et al., 1998) and the role of 343 endocytotic-active cells made up BH complex in purifying the hemolymph from allogenic 344 compounds (Beuerlein and Schipp, 1998; Beuerlein et al., 2002; Schipp and Hevert, 1981). 345 The absence of lysozyme-like activity found in the plasma supports our previous finding of 346 hemolymph lysozyme in hemocytes alone (Le Pabic et al., 2012), but contrast with those 347 found in the octopods E. cirrhosa and Octopus vulgaris (Grimaldi et al., 2013; Malham, 348 1996). The high activity found in WB - the site of hemocyte formation, is consistent with the 349 previously suggested association of mature hemocytes ( $80 \%$ of adult cuttlefish WB) with 350 lysozyme-like enzymes (Claes, 1996). Globally, the high lysozyme activities found in 351 cuttlefish circulatory organs suggested not only intracellular action after endocytosis but also 352 secretion in plasma as previously described in bivalves (Cheng et al., 1977, 1975). Apart from 353 its bactericidal activity, some studies highlighted the lysozyme property as modulator of the 354 immune response by interacting with compounds such as the complement pathway or lectins 355 (e.g. Park et al., 2007; Rao et al., 2010; Wang and Zhang, 2010; Wilson and Ratcliffe, 2000). 356 In order to investigate more deeply lysozyme roles in cuttlefish immunity, it will be 
interesting to confirm such secretion in plasma and to determine its triggering parameters (e.g. infection, stress).

Surprisingly gill activity $\left(0.3 \pm 0.2 \mu \mathrm{g}\right.$ HEW lysozyme eq. $\mathrm{mg}$ protein $\left.{ }^{-1}\right)$ was among the lowest activity found whereas it is an organ (1) constantly exposed to water and therefore potential pathogens and (2) with inner folded epithelia suggesting some excretory function (Schipp and Boletzky, 1975; Schipp et al., 1979, 1971). This low activity may result from the healthy state of sampled cuttlefish. It could be thus interesting to follow potential increase of lysozyme-like activity in cuttlefish gill following an exposure to bacterial contamination, as shown in fish (Larsen et al., 2009; Mai et al., 2014) and abalone (Bathige et al., 2013).

Among digestive system organs, highest activity was found in the PSG $(1.7 \pm 0.3 \mu \mathrm{g}$ HEW lysozyme eq. mg protein $\left.^{-1}\right)$, which was significantly higher than in cecum, DG $(0.4 \pm$ 0.1 and $0.2 \pm 0.1 \mu \mathrm{g}$ HEW lysozyme eq. $\mathrm{mg}_{\text {protein }}{ }^{-1}$, respectively) and DGA. Such results are consistent with lytic lysosomal enzyme activities reported in the cephalopod E. cirrhosa anterior salivary glands (Malham et al., 1998), and octopod and oegopsid squid paralarvae PSG (Boucaud-Camou and Roper, 1995). PSG-associated lysozyme-like enzymes may be

372 involved in (1) venom diffusion, (2) "external" digestive processes (Boucaud-Camou and 373 Roper, 1995), (3) plasma depuration (Stuart, 1968), and/or (4) to prevent digestive duct 374 infection. This last possibility is consistent with the decreasing lysozyme-like activity found 375 between the PSG and the cecum, which may result from PSG excretions from uncompleted 376 digestion due to the short time period between cuttlefish fishing and dissection, the low 377 holding temperature $\left(15^{\circ} \mathrm{C}\right)$, and the few secretion ability of Stc (Boucaud-Camou, 1973). 378 Moreover, due to their known chitinase property in certain invertebrates, lysozymes from 379 PSG could also contribute to shell digestion of crustaceans -the most important cuttlefish meal (Goto et al., 2007; Herreweghe and Michiels, 2012). 
Because of the general need to regulate proteases, we hypothesized a ubiquitous distribution of PIs in S. officinalis compartments. Our results support this hypothesis as PI activity was found in all studied compartments, albeit significant differences were found

(Figure 3). As previously described in the squid Loligo vulgaris (Tschesche and von Rücker, 1973), PI activity was highest in digestive system organs - DG, DGA, Stc and cecum, where 387 proteolytic enzymes (as serine proteases) play a major role in S. officinalis (Perrin, 2004; Balti 388 et al., 2012, 2009; Boucaud-Camou, 1974). Consistent with its role in digestive enzyme 389 synthesis (proteases)(Boucaud-Camou, 1974), highest PI activity was found in the DG $(2.2 \pm$ $390 \quad 0.2 \mathrm{TI} \% \mu \mathrm{g} \operatorname{prot}^{-1}$ ), as previously shown in cephalopods (Ishikawa et al., 1966; Kishimura et 391 al., 2010, 2001; Sof'ina et al., 1988). PI activities found in the DGA, Stc and cecum (1.8 \pm $3920.3,1.7 \pm 0.4,1.5 \pm 0.4 \mathrm{TI} \% \mu \mathrm{g} \operatorname{prot}^{-1}$ ) might mostly result mainly from DG enzymatic 393 excretions. Indeed, among these three organs, protease synthesis was clearly highlighted in 394 cecum epithelial cells alone, but in much lower amounts than in the DG (Boucaud-Camou, 395 1974). The absorption function of the cecum implies a prolonged contact with digestive fluids 396 enriched in DG proteases (Boucaud-Camou and Pequignat, 1973). Therefore, a need to 397 control and/or protect cecum epithelia against proteases may constitute a role for associated 398 PI-activity. Lastly, it was previously argued that DGA-associated proteolytic activity is likely 399 to result from extrinsic sources because to its function (1) as excretory route for enzymes and 400 digestive fluids between DG, Stc and cecum (Boucaud-Camou, 1974; Boucaud-Camou and 401 Boucher-Rodoni, 1983), but also (2) as main absorption site for small molecules from 402 protease rich digestive fluid (Boucaud-Camou and Pequignat, 1973). Finally, no digestive 403 enzymatic activity has been found in Stc epithelium by Boucaud-Camou (1973), but this 404 organ involved in mechanical digestion collects enzyme excretion from DG and probably 405 from PSG (Boucaud-Camou and Boucher-Rodoni, 1983). Concerning PSG, the detected 
activity may be involved in the regulation of proteases present in the cephalopod saliva

407 (Malham et al., 1998) such as chymotrypsin, which is concentrated in this tissue (Perrin, 2004). However cephalopod salivary glands are also known to contain biologically active amines and toxins (Boucaud-Camou and Boucher-Rodoni, 1983; Boyle and Rodhouse, 2005; Fry et al., 2009; Nagai, 2012; Undheim et al., 2010), and PIs may have a synergistic effect with toxins as described for proteases in E. cirrhosa saliva (Grisley and Boyle, 1987). This suggests the presence of different PIs in this tissue than in other digestive organs.

PI activities were lower in remaining compartments. Similar PI activities averaging at reported in E. cirrhosa (Malham et al., 1998), except in the plasma. However, a PI - $\alpha_{2}$ macroglobulin, was described as the second-most abundant protein found in the S. officinalis plasma (Armstrong, 1992; Thøgersen et al., 1992; Vanhoorelbeke et al., 1994). $\alpha_{2}$ macroglobulin acts by surrounding a wide range of protease molecules - including trypsin, to prevent enzyme-substrate reaction, but does not prevent reaction with low molecular weight substrates such as the BAPNA used in our study. Therefore, the low PI activity found in our plasma assays $\left(<0.1 \mathrm{TI} \% \mu \mathrm{g} \operatorname{prot}^{-1}\right)$ did not reflect $\alpha_{2}$-macroglobulin activity. Other studies on tissues of terrestrial gastropod Helix pomatia and cephalopod L. vulgaris evidenced at least two different groups of PIs. A heat- and acid-stable group (I) and a group sensitive to denaturation (II) differently located in both mollusks. Whereas H. pomatia presented group I PIs only in its external organs, almost all sampled tissues (organ of the digestive tract, gills, 426 epithelial barriers) of the squid presented PIs of this group, except sexual organs which 427 contained group II PIs in both mollusks (Tschesche and Dietl, 1972; Tschesche and von 428 Rücker, 1973). Each group was able to inhibit a wide range of serine proteases involved in 429 digestive and immune processes (trypsin, chymotrypsin, plasmin, kallikrein) with different 430 yields. These observations suggested that PIs assessed in our study belong to the same PI 
group (I), to the exception of the plasma. Thus, while our results highlight the presence of PI activity in cuttlefish respiratory and circulatory compartments, they also demonstrate the need for more detailed approaches to dissect out which specific PIs are associated with individual organs.

\section{Acknowledgments}

436

This work was supported by the European, Interreg IV-A CRESH and CHRONEXPO projects. This study was partly conducted in the CREC (Centre de Recherche en Environnement Côtier) at Luc-sur-mer (Normandie, France). We would like to thank Doctors Pierre Le Pabic and Thomas Lacoue-Labarthe for advices and help in English.

\section{References}

Alpuche, J., Pereyra, A., Mendoza-Hernández, G., Agundis, C., Rosas, C., Zenteno, E., 2010. Purification and partial characterization of an agglutinin from Octopus maya serum. Comp. Biochem. Physiol. Part B Biochem. \& Mol. Biol. 156, 1-5.

Ansari, Z.A., Desilva, C., Badesab, S., 2012. Total petroleum hydrocarbon in the tissues of some commercially important fishes of the Bay of Bengal. Mar. Pollut. Bull. 64, 2564-8.

Amparyup, P., Charoensapsri, W., Tassanakajon, A., 2013. Prophenoloxidase system and its role in shrimp immune responses against major pathogens. Fish \& Shellfish Immunol. 34, 990-1001.

Andrews, P.L.R., Darmaillacq, A.-S., Dennison, N., Gleadall, I.G., Hawkins, P., Messenger, J.B., Osorio, D., Smith, V.J., Smith, J.A., 2013. The identification and management of pain, suffering and distress in cephalopods, including anaesthesia, analgesia and humane killing. J. Exp. Mar. Bio. Ecol. 447, 46-64.

Arakane, Y., Muthukrishnan, S., Beeman, R.W., Kanost, M.R., Kramer, K.J., 2005. Laccase 2 is the phenoloxidase gene required for beetle cuticle tanning. Proc. Natl. Acad. Sci. U. S. A. 102, 11337-11342.

Armstrong, P.B., 1992. Humoral immunity: $\alpha_{2}$-macroglobulin activity in the plasma of mollusks. The Veliger 35, 161-164.

Asano, T., Ashida, M., 2001. Cuticular pro-phenoloxidase of the silkworm, Bombyx mori. Purification and demonstration of its transport from hemolymph. J. Biol. Chem. 276, 11100-11112. 
Balti, R., Barkia, A., Bougatef, A., Ktari, N., Nasri, M., 2009. A heat-stable trypsin from the hepatopancreas of the cuttlefish (Sepia officinalis): Purification and characterisation. Food Chem. 113, 146-154.

Balti, R., Bougherra, F., Bougatef, A., Hayet, B.K., Nedjar-Arroume, N., Dhulster, P., Guillochon, D., Nasri, M., 2012. Chymotrypsin from the hepatopancreas of cuttlefish (Sepia officinalis) with high activity in the hydrolysis of long chain peptide substrates: Purification and biochemical characterisation. Food Chem. 130, 475-484.

Bassaglia, Y., Buresi, A., Franko, D., Andouche, A., Baratte, S., Bonnaud, L., 2013. Sepia officinalis: A new biological model for eco-evo-devo studies. J. Exp. Mar. Bio. Ecol. 447, 4-13.

Bathige, S.D.N.K., Umasuthan, N., Whang, I., Lim, B.-S., Jung, H.-B., Lee, J., 2013. Evidences for the involvement of an invertebrate goose-type lysozyme in disk abalone immunity: cloning, expression analysis and antimicrobial activity. Fish \& Shellfish Immunol. 35, 1369-79.

Beuerlein, K., Löhr, S., Westermann, B., Ruth, P., Schipp, R., 2002. Components of the cellular defense and detoxification system of the common cuttlefish Sepia officinalis (Mollusca, Cephalopoda). Tissue Cell 34, 390-396.

Beuerlein, K., Schimmelpfennig, R., Westermann, B., Ruth, P., Schipp, R., 1998. Cytobiological studies on hemocyanin metabolism in the branchial heart complex of the common cuttlefish Sepia officinalis (Cephalopoda, Dibranchiata). Cell Tissue Res. 292, $587-595$.

Beuerlein, K., Schipp, R., 1998. Cytomorphological aspects on the response of the branchial heart complex of Sepia officinalis L. (Cephalopoda) to xenobiotics and bacterial infection. Tissue Cell 30, 662-671.

Beuerlein, K., Westermann, B., Ruth, P., Schimmelpfennig, R., Schipp, R., 2000. Hemocyanin re-uptake in the renal and branchial heart appendages of the coleoid cephalopod Sepia officinalis. Cell Tissue Res. 301, 413-421.

Blaschko, H., 1941. Amine oxidase in Sepia officinalis. J. Physiol. 99, 364-369.

Blaschko, H., Hawkins, J., 1952. Observations on amine oxidase in cephalopods. J. Physiol. $118,88-93$.

Boucaud-Camou, E., 1973. Etude de 1'appareil digestif de Sepia officinalis L. (Mollusque Céphalopode). Essai d'analyse expérimentale des phénomènes digestifs. Université de Caen.

Boucaud-Camou, E., 1974. Localisation d'activités enzymatiques impliquées dans la digestion chez Sepia officinalis L. Arch. Zool. Expérimentale Générale 115, 5-27.

Boucaud-Camou, E., Boucher-Rodoni, R., 1983. Feeding and digestion in Cephalopods, in: Wilbur, K., Saleudinn, A.M.S. (Eds.), The Mollusca Vol. 5 Physiology Part. 2. New York and London, pp. 149-187. 
Boucaud-Camou, E., Pequignat, E., 1973. Etude expérimentale de l'absorption digestive chez Sepia officinalis L. forma Funct. 6, 93-112.

Boucaud-Camou, E., Roper, C.F.E., 1995. Digestive enzymes in paralarval cephalopods. Bull. Mar. Sci. 57, 313-327.

Boyle, P., Rodhouse, P., 2005. Ecology and Fisheries, 1st ed. Blackwell Publishing, Ames, Iowa.

Bradford, M.M., 1976. A rapid and sensitive method for the quantitation of microgram quantities of protein utilizing the principle of protein-dye binding. Anal. Biochem. 72, $248-254$.

Burmester, T., 2002. Origin and evolution of arthropod hemocyanins and related proteins. J. Comp. Physiol. B Biochem. Syst. Environ. Physiol. 172, 95-107.

Bustamante, P., Bertrand, M., Boucaud-Camou, E., Miramand, P., 2006. Subcellular distribution of $\mathrm{Ag}, \mathrm{Cd}, \mathrm{Co}, \mathrm{Cu}, \mathrm{Fe}, \mathrm{Mn}, \mathrm{Pb}$, and $\mathrm{Zn}$ in the digestive gland of the common cuttlefish Sepia officinalis. J. Shellfish Res. 25, 987-993.

Campello, S., Beltramini, M., Giordano, G., Di Muro, P., Marino, S.M., Bubacco, L., 2008. Role of the tertiary structure in the diphenol oxidase activity of Octopus vulgaris hemocyanin. Arch. Biochem. Biophys. 471, 159-167.

Castellanos-Martínez, S., Gestal, C., 2013. Pathogens and immune response of cephalopods. J. Exp. Mar. Bio. Ecol. 447, 14-22.

Cerenius, L., Lee, B.L., Söderhäll, K., 2008. The proPO-system: pros and cons for its role in invertebrate immunity. Trends Immunol. 29, 263-271.

Cerenius, L., Söderhäll, K., 2004. The prophenoloxidase-activating system in invertebrates. Immunol. Rev. 198, 116-126.

Cheng, T.C., Chorney, M.J., Yoshino, T.P., 1977. Lysozyme like activity in the hemolymph of Biomphalaria glabrata challenged with bacterial. J. Invertebr. Pathol. 29, 170-174.

Cheng, T.C., Rodrick, G.E., Foley, D. a, Koehler, S. a, 1975. Release of lysozyme from hemolymph cells of Mercenaria mercenaria during phagocytosis. J. Invertebr. Pathol. $25,261-5$.

Claes, M.F., 1996. Functional morphology of the white bodies of the cephalopod mollusc Sepia officinalis. Acta Zool. 77, 173-190.

Coates, C.J., Nairn, J., 2014. Diverse immune functions of hemocyanins. Dev. \& Comp. Immunol. 45, 43-55.

Costa, P.M., Rodrigo, A.P., Costa, M.H., 2014. Microstructural and histochemical advances on the digestive gland of the common cuttlefish, Sepia officinalis L. Zoomorphology $133,59-69$. 
D’Aniello, A., Strazzullo, L., D’Onofrio, G., Pischetola, M., 1986. Electrolytes and nitrogen compounds of body fluids and tissues of Octopus vulgaris Lam. J. Comp. Physiol. B $156,503-509$.

Decleir, W., Richard, A., Lemaire, J., Wolf, G., 1976. L'hémocyanine et la glande branchiale de Sepia officinalis L. (mollusque cephalopode). Ann. la Société R. Zool. Belgique 106, $133-144$.

Decleir, W., Vlaeminck, A., Geladi, P., Van Grieken, R., 1978. Determination of proteinbound copper and zinc in some organs of the cuttlefish Sepia officinalis L. Comp. Biochem. Physiol. 60B, 347-350.

Dodor, D.E., Hwang, H.-M., Ekunwe, S.I.N., 2004. Oxidation of anthracene and benzo[a]pyrene by immobilized laccase from Trametes versicolor. Enzyme Microb. Technol. 35, 210-217.

Fiołka, M.J., Zagaja, M.P., Hułas-Stasiak, M., Wielbo, J., 2012. Activity and immunodetection of lysozyme in earthworm Dendrobaena veneta (Annelida). J. Invertebr. Pathol. 109, 83-90.

Ford, L.A., 1992. Host defense mechanisms of cephalopods. Annu. Rev. Fish Dis. 2, 25-41.

Franssens, V., Simonet, G., Breugelmans, B., Van Soest, S., Van Hoef, V., Vanden Broeck, J., 2008. The role of hemocytes, serine protease inhibitors and pathogen-associated patterns in prophenoloxidase activation in the desert locust, Schistocerca gregaria. Peptides 29, 235-41.

Fry, B.G., Roelants, K., Norman, J. a, 2009. Tentacles of venom: toxic protein convergence in the Kingdom Animalia. J. Mol. Evol. 68, 311-321.

Ghafoori, Z., Heidari, B., Farzadfar, F., Aghamaali, M., 2014. Variations of serum and mucus lysozyme activity and total protein content in the male and female Caspian kutum (Rutilus frisii kutum, Kamensky 1901) during reproductive period. Fish \& Shellfish Immunol. 37, 139-46.

Ghiretti, F., 1966. Molluscan hemocyanins, in: Wilburg, K.M., Young, C.M. (Eds.), Physiology of Mollusca. Vol. II. Academic press, London, New York, pp. 233-248.

Gomez, D., Sunyer, J.O., Salinas, I., 2013. The mucosal immune system of fish: the evolution of tolerating commensals while fighting pathogens. Fish \& Shellfish Immunol. 35, 1729-39.

Goto, T., Abe, Y., Kakuta, Y., Takeshita, K., Imoto, T., Ueda, T., 2007. Crystal structure of Tapes japonica Lysozyme with substrate analogue: structural basis of the catalytic mechanism and manifestation of its chitinase activity accompanied by quaternary structural change. J. Biol. Chem. 282, 27459-67.

Grimaldi, A.M., Belcari, P., Pagano, E., Cacialli, F., Locatello, L., 2013. Immune responses of Octopus vulgaris (Mollusca: Cephalopoda) exposed to titanium dioxide nanoparticles. J. Exp. Mar. Bio. Ecol. 447, 123-127. 
Grisley, M.S., Boyle, P.R., 1987. Bioassay and proteolytic activity of digestive enzymes from octopus saliva. Comp. Biochem. Physiol. Part B Comp. Biochem. 88, 1117-1123.

Haffner, B., Wieser, W., 1981. Environmental effects on the dopa oxidase system in the skin of Rana temporaria and R. esculenta. Comp. Biochem. Physiol. Part B Comp. Biochem. $68,57-63$.

Hanlon, R.T., Messenger, J.B., 1988. Adaptive coloration in young cuttlefish (Sepia officinalis L.): the morphology and development of body patterns and their relation to behaviour. Philos. Trans. R. Soc. B Biol. Sci. 320, 437-487.

Hansen, G.H., Olafsen, J.A., 1999. Bacterial interactions in early life stages of marine cold water fish. Microb. Ecol. 38, 1-26.

Harms, C.A., Lewbart, G.A., McAlarney, R., Christian, L.S., Geissler, K., Lemons, C., 2006. Surgical excision of mycotic (Cladosporium sp.) granulomas from the mantle of a cuttlefish (Sepia officinalis). J. Zoo Wildl. Med. 37, 524-30.

Heath-Heckman, E.A.C., McFall-Ngai, M.J., 2011. The occurrence of chitin in the hemocytes of invertebrates. Zoology 114, 191-198.

Herreweghe, J.M. Van, Michiels, C.W., 2012. Invertebrate lysozymes: Diversity and distribution, molecular mechanism and in vivo function. J. Biosci. 37, 327-348.

Hikima, J., Minagawa, S., Hirono, I., Aoki, T., 2001. Molecular cloning, expression and evolution of the Japanese flounder goose-type lysozyme gene, and the lytic activity of its recombinant protein. Biochim. Biophys. Acta 1520, 35-44.

Hochberg, F.G., 1990. Diseases of Mollusca: Cephalopoda. Diseases caused by Protistans and Metazoans, in: Kinne, O. (Ed.), Diseases of Marine Animals. Introduction, Cephalopoda, Annelida, Crustacea, Chaetognatha, Echinodermata, Urochordata, III. Biologische Anstalt, Helgoland, Hamburg, Germany, pp. 46-202.

Ishikawa, S., Nakamura, K., Shudo, K., Kitabayashi, K., 1966. Studies on fish soluble Iprotease inhibitor in squid liver. Suisanchyo Hokkaido-ku Suisan Kenkyusho Kenkyu Hokoku 31, 112-119.

Itoh, N., Okada, Y., Takahashi, K.G., Osada, M., 2010. Presence and characterization of multiple mantle lysozymes in the Pacific oyster, Crassostrea gigas. Fish Shellfish Immunol. 29, 126-135.

Itoh, N., Xue, Q., Li, Y., Cooper, R.K., La Peyre, J.F., 2007. cDNA cloning and tissue expression of plasma lysozyme in the eastern oyster, Crassostrea virginica. Fish Shellfish Immunol. 23, 957-68.

Iwanaga, S., Lee, B.L., 2005. Recent advances in the innate immunity of invertebrate animals. J. Biochem. Mol. Biol. 38, 128-150. 
King, A.J., Henderson, S.M., Schmidt, M.H., Cole, A.G., Adamo, S. a, 2005. Using ultrasound to understand vascular and mantle contributions to venous return in the cephalopod Sepia officinalis L. J. Exp. Biol. 208, 2071-2082.

Kishimura, H., Nagai, Y., Fukumorita, K., Chiba, S., Nakajima, S., Klomklao, S., Nalinanon, S., Benjakul, S., Chun, B.-S., 2010. Acid- and heat-stable trypsin inhibitory peptide from the viscera of japanese common squid (Todarodes pacificus). J. Food Biochem. 34, 748763.

Kishimura, H., Saeki, H., Hayashi, K., 2001. Isolation and characteristics of trypsin inhibitor from the hepatopancreas of a squid (Todarodes pacificus). Comp. Biochem. Physiol. B. Biochem. Mol. Biol. 130, 117-123.

Lacoue-Labarthe, T., Bustamante, P., Hörlin, E., Luna-Acosta, A., Bado-Nilles, A., ThomasGuyon, H., 2009. Phenoloxidase activation in the embryo of the common cuttlefish Sepia officinalis and responses to the $\mathrm{Ag}$ and $\mathrm{Cu}$ exposure. Fish Shellfish Immunol. 27, 516-521.

Larsen, A.N., Solstad, T., Svineng, G., Seppola, M., Jørgensen, T.Ø., 2009. Molecular characterisation of a goose-type lysozyme gene in Atlantic cod (Gadus morhua L.). Fish Shellfish Immunol. 26, 122-32.

Le Pabic, C., Goux, D., Serpentini, A., Lebel, J.-M., Koueta, N., 2012. Characterization of Sepia officinalis haemocytes, primary-culture development and enzymatic assays on serum and haemocyte fractions, in: Cephalopod International Advisory Council Symposium - Official Program. Florianopolis, SC, Brazil, p. 41.

Lemaire, J., Richard, A., Decleir, W., 1977. Le foie embryonnaire de Sepia officinalis L. (mollusque cephalopode): 1. Organogenèse. Haliotis 6, 287-296.

Loker, E.S., Adema, C.M., Zhang, S.-M., Kepler, T.B., 2004. Invertebrate immune systemsnot homogeneous, not simple, not well understood. Immunol. Rev. 198, 10-24.

Luna-Acosta, A., 2010. Les phénoloxydases chez l'huître creuse Crassostrea gigas : biomarqueurs potentiels de stress environnemental. Université de La Rochelle.

Luna-Acosta, A., Kanan, R., Le Floch, S., Huet, V., Pineau, P., Bustamante, P., ThomasGuyon, H., 2011a. Enhanced immunological and detoxification responses in Pacific oysters, Crassostrea gigas, exposed to chemically dispersed oil. Water Res. 45, 41034118.

Luna-Acosta, A., Rosenfeld, E., Amari, M., Fruitier-Arnaudin, I., Bustamante, P., ThomasGuyon, H., 2010. First evidence of laccase activity in the Pacific oyster Crassostrea gigas. Fish \& Shellfish Immunol. 28, 719-726.

Luna-Acosta, A., Thomas-Guyon, H., Amari, M., Rosenfeld, E., Bustamante, P., FruitierArnaudin, I., others, 2011b. Differential tissue distribution and specificity of phenoloxidases from the Pacific oyster Crassostrea gigas. Comp. Biochem. Physiol. Part B Biochem. \& Mol. Biol. 159, 220-226. 
Mackintosh, J.A., 2001. The antimicrobial properties of melanocytes, melanosomes and melanin and the evolution of black skin. J. Theor. Biol. 211, 101-113.

Mai, W., Liu, P., Chen, H., Zhou, Y., 2014. Cloning and immune characterization of the ctype lysozyme gene in red-spotted grouper, Epinephelus akaara. Fish \& Shellfish Immunol. 36, 305-14.

Malham, S.K., 1996. Immunobiology of Eledone cirrhosa (Lamarck). University of Wales, Bangor, North Wales, UK.

Malham, S.K., Runham, N.W., Secombes, C.J., 1998. Lysozyme and antiprotease activity in the lesser octopus Eledone cirrhosa (Lam.) (Cephalopoda). Dev. Comp. Immunol. 22, $27-37$.

Mangold, K., Bidder, A.M., 1989. Appareils respiratoire et circulatoire : respiration et circulation, in: Traité de Zoologie, Anatomie, Systématique, Biologie. Céphalopodes, Tome V. Grassé, Pierre-Paul, Paris, pp. 387-434.

Manubens, A., Salazar, F., Haussmann, D., Figueroa, J., Del Campo, M., Pinto, J.M., Huaquín, L., Venegas, A., Becker, M.I., 2010. Concholepas hemocyanin biosynthesis takes place in the hepatopancreas, with hemocytes being involved in its metabolism. Cell Tissue Res. 342, 423-435.

Martoja, M., Marcaillou, C., 1993. Localisation cytologique du cuivre et de quelques autres métaux dans la glande digestive de la seiche, Sepia officinalis L. (Mollusque Céphalopode). Can. J. Fish. Aquat. Sci. 50, 542-550.

Masuda, T., Otomo, R., Kuyama, H., Momoji, K., Tonomoto, M., Sakai, S., Nishimura, O., Sugawara, T., Hirata, T., 2012. A novel type of prophenoloxidase from the kuruma prawn Marsupenaeus japonicus contributes to the melanization of plasma in crustaceans. Fish \& Shellfish Immunol. 32, 61-68.

McFall-Ngai, M., Nyholm, S. V, Castillo, M.G., 2010. The role of the immune system in the initiation and persistence of the Euprymna scolopes-Vibrio fischeri symbiosis. Semin. Immunol. 22, 48-53.

Messenger, J.B., 2001. Cephalopod chromatophores: neurobiology and natural history. Biol. Rev. Camb. Philos. Soc. 76, 473-528.

Miramand, P., Bentley, D., 1992. Concentration and distribution of heavy metals in tissues of two cephalopods, Eledone cirrhosa and Sepia officinalis, from the Rench coast of the English Channel. Mar. Biol. 114, 407-414.

Miramand, P., Guary, J.C., 1980. High concentrations of some heavy metals in tissues of the Mediterranean Octopus. Bull. Environ. Contam. Toxicol. 24, 783-788.

Nagai, H., 2012. Protein Toxin of Cephalopods, in: Fattorusso, E., Gerwick, W.H., Taglialatela-Scafati, O. (Eds.), Handbook of Marine Natural Products. Springer Netherlands, Dordrecht, pp. 1412-1413. 
Park, J.-W., Kim, C.-H., Kim, J.-H., Je, B.-R., Roh, K.-B., Kim, S.-J., Lee, H.-H., Ryu, J.-H., Lim, J.-H., Oh, B.-H., Lee, W.-J., Ha, N.-C., Lee, B.-L., 2007. Clustering of peptidoglycan recognition protein-SA is required for sensing lysine-type peptidoglycan in insects. Proc. Natl. Acad. Sci. U. S. A. 104, 6602-7.

Perrin, A., 2004. Etude expérimentale des capacités digestives chez la seiche, Sepia officinalis L. (Mollusque, Céphalopode): Impact de l'alimentation, indice de condition nutritionnelle et formulation d'un aliment artificiel. Université de Caen.

Pryor, M.G.M., 1940. On the hardening of the cuticle of insects. Proc. R. Soc. London. Ser. B $128,393-407$.

Rao, X.-J., Ling, E., Yu, X.-Q., 2010. The role of lysozyme in the prophenoloxidase activation system of Manduca sexta: an in vitro approach. Dev. \& Comp. Immunol. 34, 264-71.

Rocca, E., 1969. Copper distribution in Octopus vulgaris Lam. hepatopancreas. Comp. Biochem. Physiol. 28, 67-82.

Rögener, W., Renwrantz, L., Unlenbruck, G., 1985. Isolation and characterization of a lectin from the hemolymph of the cephalopod Octopus vulgaris (Lam.) inhibited by $\alpha$-d-lactose and N-acetyl-lactosamine. Dev. \& Comp. Immunol. 9, 605-616.

Rowley, A.F., Powell, A., 2007. Invertebrate immune systems specific, quasi-specific, or nonspecific? J. Immunol. 179, 7209-7214.

Ruth, P., Blum, W., Bille, J., 1996. Immunocytochemical reaction of a haemocyanin antibody in the midgut gland of Nautilus (Cephalopoda, Tetrabranchiata). Experientia 52, 549553.

Safi, G., 2013. Etude de la variabilité spatio-temporelle des caractéristiques physiologiques des jeunes stades de vie de la seiche Sepia officinalis L . en Manche. Université de Caen Basse-Normandie.

Saurabh, S., Sahoo, P.K., 2008. Lysozyme: an important defence molecule of fish innate immune system. Aquac. Res. 39, 223-239.

Schipp, R., 1987. The blood vessels of cephalopods. A comparative morphological and functional survey. Experientia 43, 525-537.

Schipp, R., Boletzky, S. von, 1975. Morphology and function of the excretory organs in dibranchiate Cephalopods. Fortschr. Zool. 23, 89-11.

Schipp, R., Boletzky, S. von, 1976. The pancreatic appendages of dibranchiate cephalopods. I. The fine structure of the "Pancreas" in Sepioidea. Zoomorphologie 86, 81-98.

Schipp, R., Hevert, F., 1978. Distribution of copper and iron in some central organs of Sepia officinalis (Cephalopoda). A comparative study by flameless atomic absorption and electron microscopy. Mar. Biol. 47, 391-399. 
Schipp, R., Hevert, F., 1981. Ultrafiltration in the branchial heart appendage of dibranchiate cephalopods: a comparative ultrastructural and physiological study. J. Exp. Biol. 92, 2335 .

Schipp, R., Höhn, P., Ginkel, G., 1973. Elektronenmikroskopische und histochemische Untersuchungen zur funktion der branchialdrüse (parabranchialdrüse) der Cephalopoda. Zeitschrift für Zellforsch. und Mikroskopische Anat. 139, 253-269.

Schipp, R., Höhn, P., Schäfer, A., 1971. Elektronenmikroskopische und histochemische untersuchungen zur funktion des kiemenherzanhanges (pericardialdrüse) von Sepia officinalis. Zeitschrift für Zellforsch. und mikroskopische Anat. 117, 252-274.

Schipp, R., Mollenhauer, S., Boletzky, S. von, 1979. Electron microscopical and histochemical studies of differentiation and function of the cephalopod gill (Sepia officinalis L.). Zoomorphologie 93, 193-207.

Siddiqui, N.I., Akosung, R.F., Gielens, C., 2006. Location of intrinsic and inducible phenoloxidase activity in molluscan hemocyanin. Biochem. Biophys. Res. Commun. $348,1138-1144$.

Söderhäll, K., Cerenius, L., 1998. Role of the prophenoloxidase-activating system in invertebrate immunity. Curr. Opin. Immunol. 10, 23-28.

Sof'ina, E.Y., Akhnedzhanov, R.A., Pivnenko, T.N., Epshtein, L.M., 1988. Trypsin inhibitor from liver of the squid Berryteuthis magister. Chem. Nat. Compd. 24, 760-761.

Stuart, A.E., 1968. The reticulo-endothelial apparatus of the lesser octopus, Eledone cirrhosa. J. Pathol. Bacteriol. 96, 401-412.

Thøgersen, I.B., Salvesen, G., Brucato, F.H., Pizzo, S. V, Enghild, J.J., 1992. Purification and characterization of an $\alpha$-macroglobulin proteinase inhibitor from the mollusc Octopus vulgaris. Biochem. J. 285, 521-527.

Thomas-Guyon, H., Gagnaire, B., Bado-Nilles, A., Bouilly, K., Lapègue, S., Renault, T., 2009. Detection of phenoloxidase activity in early stages of the Pacific oyster Crassostrea gigas (Thunberg). Dev. Comp. Immunol. 33, 653-659.

Thompson, I., Choubert, G., Houlihan, D.F., Secombes, C.J., 1995. The effect of dietary vitamin $\mathrm{A}$ and astaxanthin on the immunocompetence of rainbow trout. Aquaculture $133,91-102$.

Tschesche, H., Dietl, T., 1972. Identifizierung der proteaseinhibitoren synthetisierenden organe der weinbergschnecke (Helix pomatia). Hoppe. Seylers. Z. Physiol. Chem. 353, 1189-1193.

Tschesche, H., von Rücker, A., 1973. Über die organverteilung der proteinase-inhibitoren breiter spezifität aus Tintenfischen (Loligo vulgaris). Hoppe. Seylers. Z. Physiol. Chem. 354, 1510-1512. 
Undheim, E. a B., Georgieva, D.N., Thoen, H.H., Norman, J. a, Mork, J., Betzel, C., Fry, B.G., 2010. Venom on ice: first insights into Antarctic octopus venoms. Toxicon 56, 897-913.

Vanhoorelbeke, K., Goossens, A., Gielsens, C., Préaux, G., 1994. An $\alpha_{2}$-macroglobulin-like proteinase inhibitor in the haemolymph of the Decabrachia cephalopod Sepia officinalis. Arch. Int. Physiol. Biochim. Biophys. 102, B25.

Wang, L., Qiu, L., Zhou, Z., Song, L., 2013. Research progress on the mollusc immunity in China. Dev. \& Comp. Immunol. 39, 2-10.

Wang, X.-W., Wang, J.-X., 2013. Diversity and multiple functions of lectins in shrimp immunity. Dev. \& Comp. Immunol. 39, 27-38.

Wang, Z., Zhang, S., 2010. The role of lysozyme and complement in the antibacterial activity of zebrafish (Danio rerio) egg cytosol. Fish \& Shellfish Immunol. 29, 773-7.

Wells, M.J., Wells, J., 1989. Water uptake in a cephalopod and the function of the so-called "Pancreas". J. Exp. Biol. 145, 215-226.

Wilson, R., Ratcliffe, N.A., 2000. Effect of lysozyme on the lectin-mediated phagocytosis of Bacillus cereus by haemocytes of the cockroach, Blaberus discoidalis. J. Insect Physiol. 46, 663-670.

Won, J.H., Hong, S.H., Shim, W.J., Yim, U.H., Kim, G.B., 2009. Persistent organochlorine pollutants in Korean offshore waters: squid (Todarodes pacificus) as a biomonitor. Mar. Pollut. Bull. 58, 1238-44.

Xue, Q., Itoh, N., Schey, K.L., Cooper, R.K., La Peyre, J.F., 2009. Evidence indicating the existence of a novel family of serine protease inhibitors that may be involved in marine invertebrate immunity. Fish \& Shellfish Immunol. 27, 250-259.

Yamada, H., Takayanagi, K., Tateishi, M., Tagata, H., Ikeda, K., 1997. Organotin compounds and polychlorinated biphenyls of livers in squid collected from coastal waters and open oceans. Environ. Pollut. 96, 217-26.

Zanna, P.T., Maida, I., Arciuli, M., Jimenez-Cervantes, C., Garcia-Borron, J.C., Cicero, R., Guida, G., 2009. Molecular cloning and biochemical characterization of the skin tyrosinase from Rana esculenta L. Comp. Biochem. Physiol. Part B Biochem. \& Mol. Biol. 152, 234-242.

Zhao, J., Qiu, L., Ning, X., Chen, A., Wu, H., Li, C., 2010. Cloning and characterization of an invertebrate type lysozyme from Venerupis philippinarum. Comp. Biochem. Physiol. B. Biochem. Mol. Biol. 156, 56-60.

Zhou, Z., Ni, D., Wang, M., Wang, Lingling, Wang, Leilei, Shi, X., Yue, F., Liu, R., Song, L., 2012. The phenoloxidase activity and antibacterial function of a tyrosinase from scallop Chlamys farreri. Fish Shellfish Immunol. 33, 375-81. 
792 Figure 1: PO-like and APO-like activities ( $\mathrm{U} \mathrm{mg} \operatorname{prot}^{-1}$ ) in 13 body compartments of 793 cuttlefish Sepia officinalis L. BH: branchial hearts, BHA: branchial heart appendages, SH: 794 systemic heart, DG: digestive gland, DGA: digestive gland appendages, PSG: posterior 795 salivary glands, Stc: stomach, WB: white bodies. The bars represent the means $( \pm \mathrm{SE})$ of 10 796 animals. Subscript letters indicate one-way ANOVA results within each activity group (POor APO-like): bars with same subscript letter are not significantly different $(\mathrm{p}<0.05) . *, * *$ and $* * *$, indicate significant PO- and APO-like activity differences in each organs for $\mathrm{p}<0.05$, $\mathrm{p}<0.01$ and $\mathrm{p}<0.001$, respectively.

800 Figure 2: Lysozyme-like activity ( $\mu \mathrm{g}$ HEW Lysozyme eq. $\mathrm{mg} \operatorname{prot}^{-1}$ ) in 13 body 801 compartments of cuttlefish Sepia officinalis L. BH: branchial hearts, BHA: branchial heart 802 appendages, SH: systemic heart, DG: digestive gland, DGA: digestive gland appendages, 803 PSG: posterior salivary glands, Stc: stomach, WB: white bodies. The bars represent the means 804 ( $\pm \mathrm{SE})$ of 10 animals. Bars with same subscript letter are not significantly different $(\mathrm{p}<0.05)$.

805 Figure 3: PI activity (TI $\% \mu \operatorname{g~prot~}^{-1}$ ) in 13 body compartments of cuttlefish Sepia officinalis 806 L. BH: branchial hearts, BHA: branchial heart appendages, SH: systemic heart, DG: digestive 807 gland, DGA: digestive gland appendages, PSG: posterior salivary glands, Stc: stomach, WB: 808 white bodies. The bars represent the means $( \pm$ SE) of 10 animals. Bars with same subscript 809 letter are not significantly different $(\mathrm{p}<0.05)$.

\section{$810 \quad$ Legends to supplementary files}

811 Figure 1S: Internal anatomy of cuttlefish Sepia officinalis L., with studied tissues. BH: 812 branchial hearts, BHA: branchial heart appendages, SH: systemic heart, DG: digestive gland, 813 DGA: digestive gland appendages, PSG: posterior salivary glands, Stc: stomach, WB: white 814 bodies (modified after Boyle and Rodhouse, 2005). 


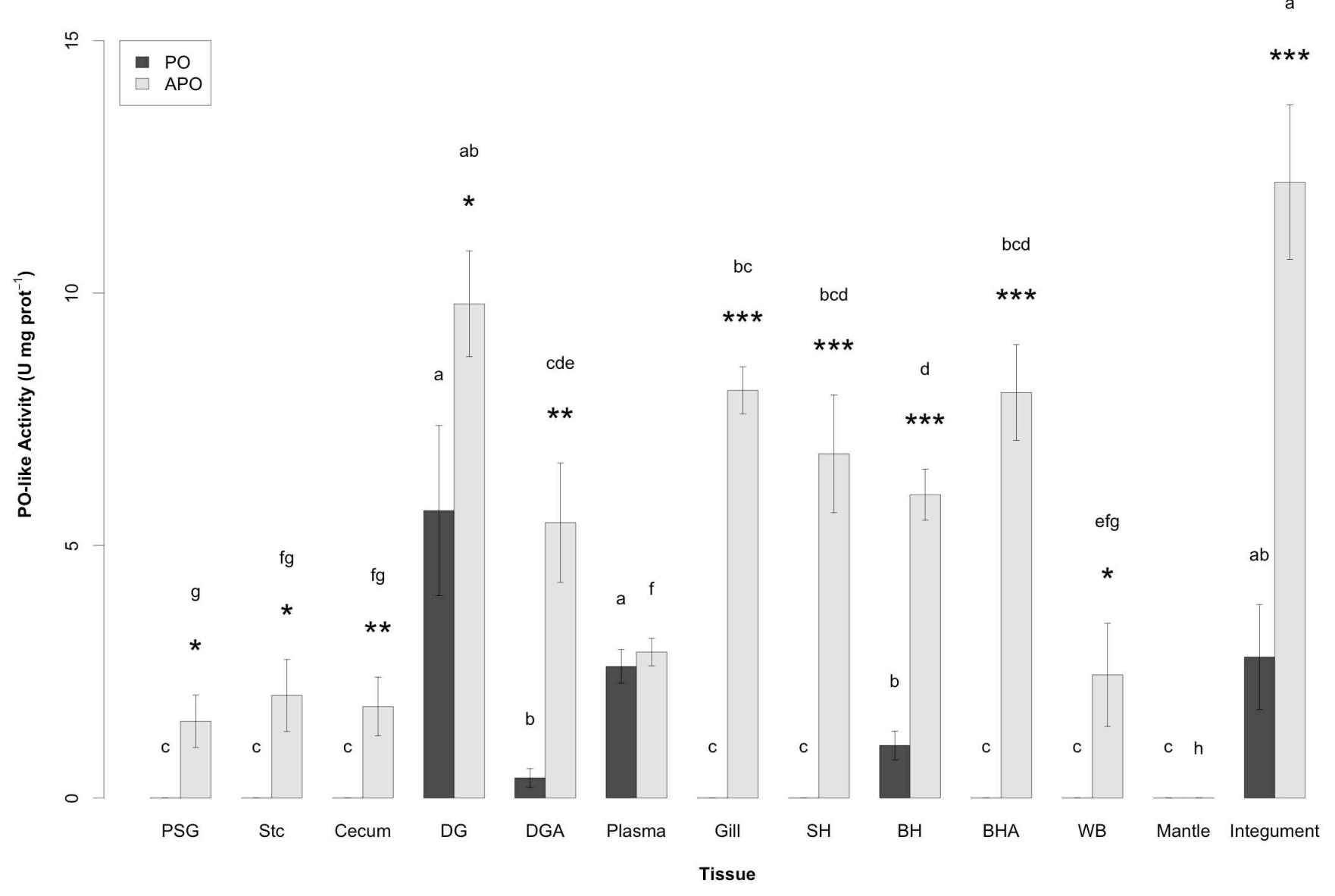




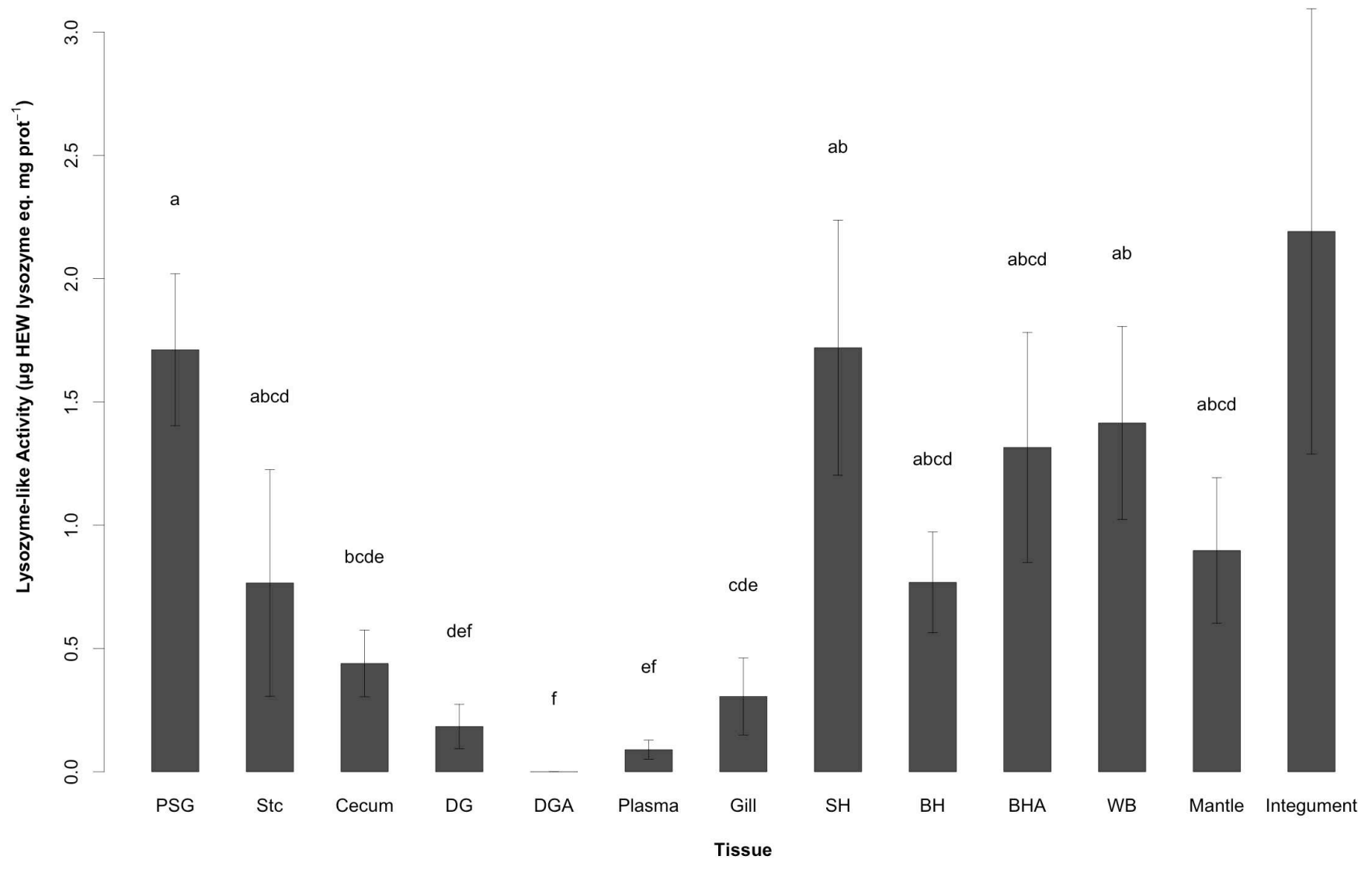




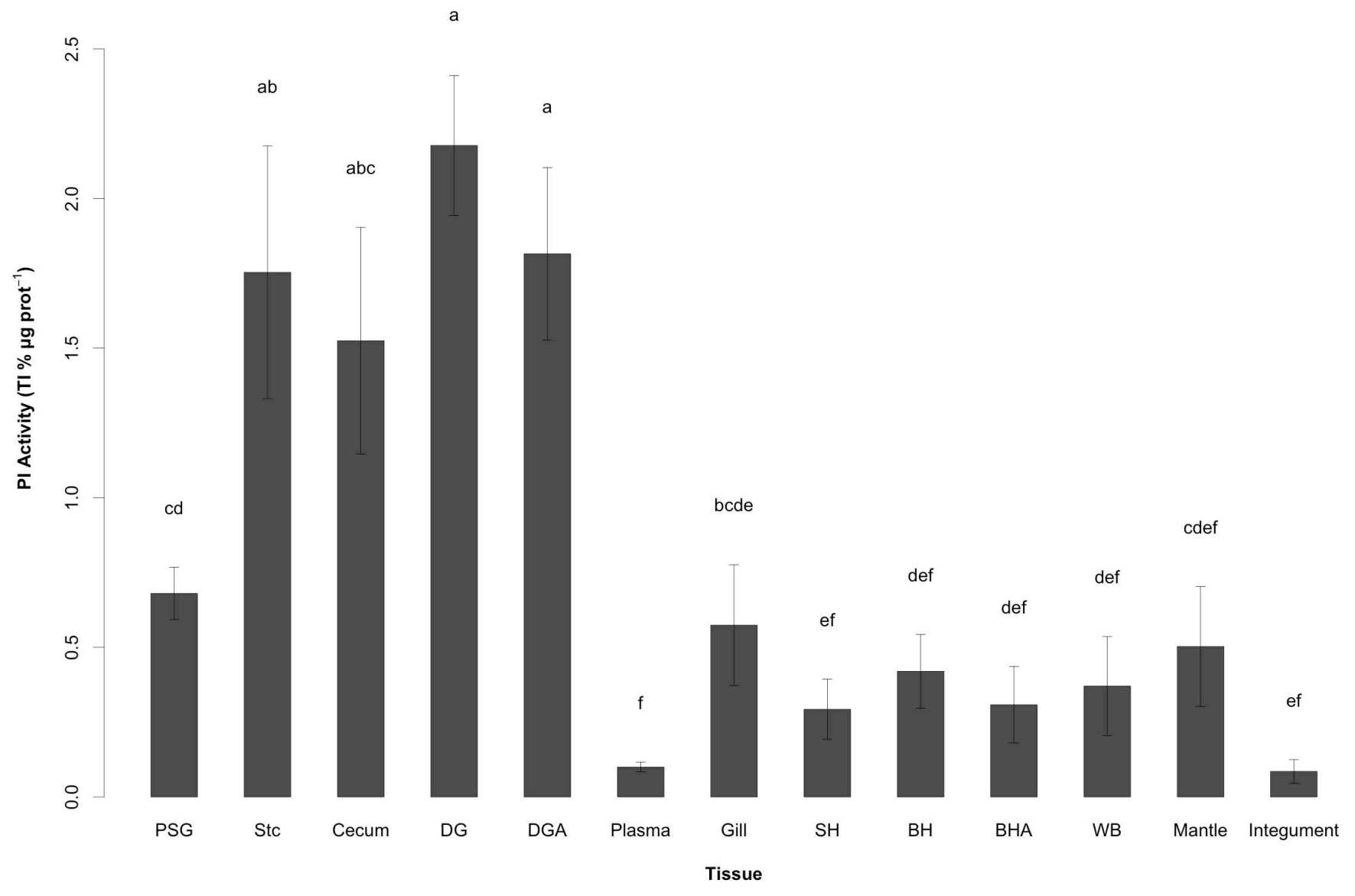




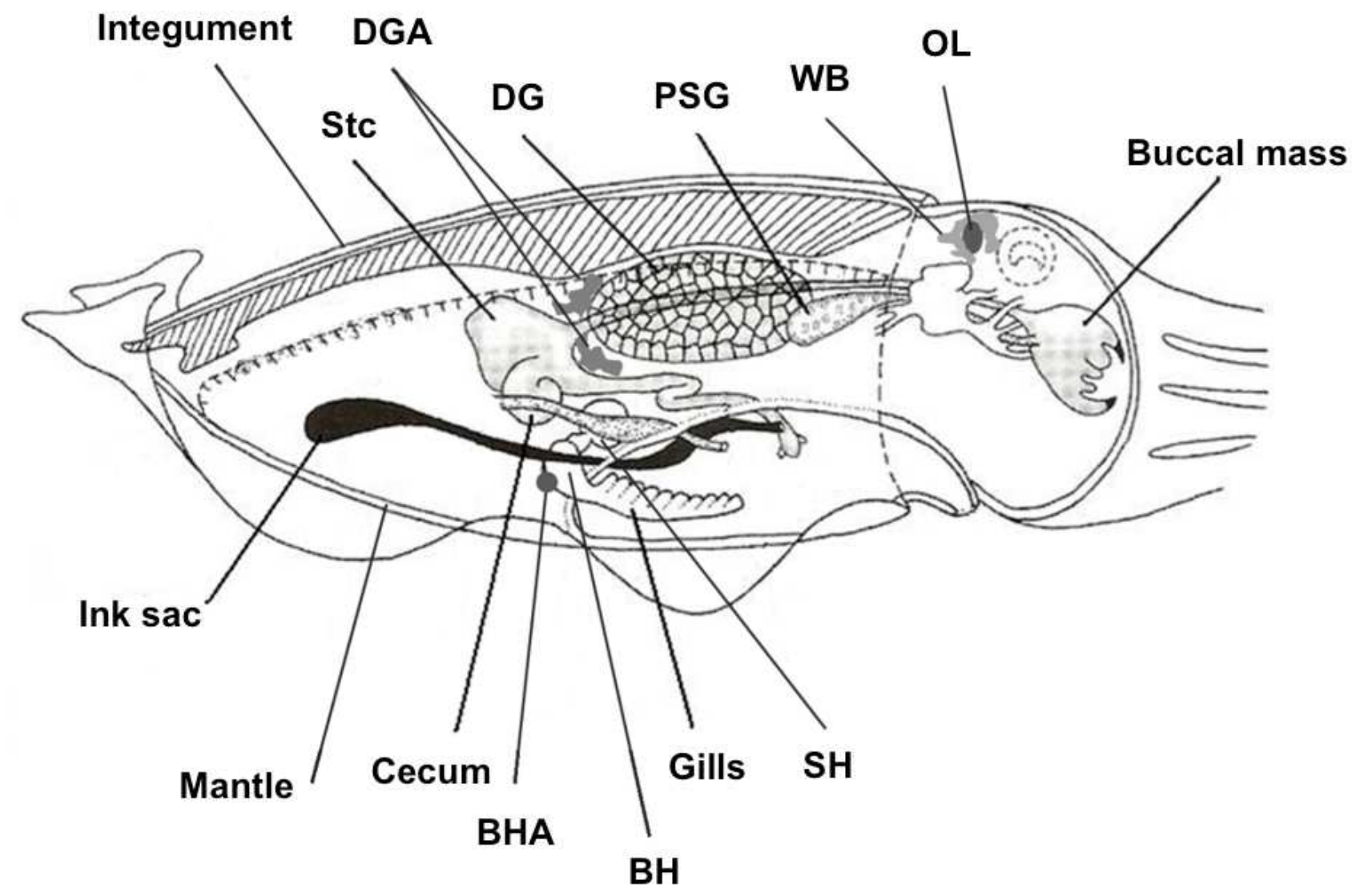

